\title{
'What remains behind': Hellenism and Romanitas in Christian Egypt after the Arab conquest
}

Book or Report Section

Published Version

Papaconstantinou, A. (2009) 'What remains behind': Hellenism and Romanitas in Christian Egypt after the Arab conquest. In: Cotton, H., Hoyland, R., Price, J. and Wasserstein, D. (eds.) From Hellenism to Islam: cultural and linguistic change in the Roman Near East. Cambridge University Press, Cambridge, pp. 447-466. ISBN 9780521875813 Available at http://centaur.reading.ac.uk/25286/

It is advisable to refer to the publisher's version if you intend to cite from the work. See Guidance on citing.

Publisher: Cambridge University Press

All outputs in CentAUR are protected by Intellectual Property Rights law, including copyright law. Copyright and IPR is retained by the creators or other 
copyright holders. Terms and conditions for use of this material are defined in the End User Agreement.

\section{www.reading.ac.uk/centaur}

\section{CentAUR}

Central Archive at the University of Reading

Reading's research outputs online 


\section{'What remains behind': Hellenism and Romanitas in Christian Egypt after the Arab conquest}

Book or Report Section

Published Version

Papaconstantinou, A. (2009) 'What remains behind': Hellenism and Romanitas in Christian Egypt after the Arab conquest. In: Cotton, H., Hoyland, R., Price, J., Wasserstein, D. (eds.) From Hellenism to Islam: cúltural and linguistic change in the Roman Near East. Cambridge University Press, Cambridge, pp. 447-466. ISBN 9780521875813 Available at http://centaur.reading.ac.uk/25286/

It is advisable to refer to the publisher's version if you intend to cite from the work.

Publisher: Cambridge University Press

All outputs in CentAUR are protected by Intellectual Property Rights law, including copyright law. Copyright and IPR is retained by the creators or other copyright holders. Terms and conditions for use of this material are defined in the End User Agreement.

\section{www.reading.ac.uk/centaur}

\section{CentAUR}

Central Archive at the University of Reading

Reading's research outputs online 


\title{
'What remains behind': Hellenism and Romanitas in Christian Egypt after the Arab conquest ${ }^{\mathrm{I}}$
}

\author{
Arietta Papaconstantinou
}

We will grieve not, rather find

Strength in what remains behind

\section{William Wordsworth ${ }^{2}$}

When the Arabs conquered Egypt in 64I, they found a deeply divided Christian church - in fact what they found amounted to two quite separate churches. They are usually called, in neutral terms, 'Chalcedonian' and 'anti-' or 'non-Chalcedonian', with reference to the Council of Chalcedon where their split had been consummated two centuries earlier. ${ }^{3}$ The two churches disagreed deeply on Christological questions, and during the two centuries that followed the Council, there were several, often heavy-handed, attempts to bring the non-Chalcedonian churches back into the imperial sphere. These events are unfortunately known mainly from polemical sources from both sides, and although this last fact does allow us to get a more balanced view, it also creates the impression that the Chalcedonian conflict dominated life in the Empire after the fifth century, an impression that certainly needs qualification.

In Egypt, the non-Chalcedonian or Monophysite church modelled itself on the highly centralised structure of the existing patriarchate of Alexandria, which, contrary to the other four patriarchates, did not have an intermediate level of metropoles between the patriarch and the local

\footnotetext{
${ }^{1}$ Early versions of this article were presented at the Eighth International Congress of Coptic Studies in Paris in July 2004 and at the Mediaeval Studies Research Seminar at the University of St Andrews in March 2005. I would like to thank Robert Hoyland for offering to publish it in the present volume and making some very useful suggestions, and Roger Bagnall, Béatrice Caseau, Muriel Debié, Denis Feissel, Jean-Luc Fournet, Garth Fowden, Charlotte Roueché and Petra Sijpesteijn for commenting on drafts, providing references and answering my queries.

2 'Intimations of Immortality from Recollections of Early Childhood'.

${ }^{3}$ On the Council of Chalcedon and its aftermath Frend 1972 remains useful on facts and sources, despite the author's highly contested interpretation of the phenomenon. More recent, but not covering the post-Justinianic period, is Gray 2005.
} 
bishops. ${ }^{4}$ Both churches had their leaders in Alexandria, heading two welldeveloped parallel networks of episcopal sees and affiliated monasteries which covered most of the valley. In 64I, the Chalcedonian church had, for over a century, been actively backed by the imperial power structure, often forcing the non-Chalcedonian hierarchy to leave the city centres and retreat to monasteries from where they managed their communities. 5 The political break with Constantinople brought about by the Arab conquest eventually weakened the position of the Chalcedonian Church. However, this outcome was not obvious from the start, and in the first decades after the conquest, the anti-Chalcedonian Church focussed most of their polemics not on Islam, but on their fellow Christians, the Chalcedonians. ${ }^{6}$ In classic Monophysite works such as the Chronicle by John of Nikiu or the History of the Patriarchs of Alexandria, the 'heresy' of the 'Romans' is given as the main reason for the loss of the province to the Arabs, while the upright faith of the 'Egyptians' is seen as the reason for the favour they found in the eyes of their new lords. It is striking that although the divide between the two groups was religious, they are described here in ethnic terms, a significant shift through which the anti-Chalcedonian authors came to identify their own church as the native one - the 'Coptic' Church - and the Chalcedonian Church as that of the 'foreigners'.7 This was but the last phase of a long process during which the Coptic language had gradually become associated with resistance to Chalcedon, while, until the conquest at least, Greek retained a more neutral status.

Most modern historians have fallen victim to this discourse, accepting in more or less critical terms the idea that, whatever problems they may have encountered under their new masters, Coptic-speaking Egyptian Christians, mostly of Monophysite denomination, were quite happy to get rid of the eastern Roman Empire and of the Greek-speaking Chalcedonians that went with it. However, several scholars have repeatedly pointed out that, according to documentary evidence, mainly that of papyri, less prone to the biased presentation of events typical of official histories, the religious divisions followed neither ethnic nor linguistic lines (the two

4 The formation and structure of the five late antique 'patriarchates' is described at length in Flusin I998.

5 See Wipszycka 2007. This was also the case in Syria: see Debié 2004.

${ }^{6}$ See for instance the episodes mentioned in the History of the Patriarchs of Alexandria $\mathrm{I}_{5}$ (Evetts I9IO: $5-6$ and I3-I4) during the patriarchate of John of Samanud (68I-9). The arrival of 'Abd al-'Aziz in 685 is presented by the History of the Patriarchs as a turning point after which the governors of Egypt marked a clear preference for the Monophysite Church. In the 760 s, however, according to the same work, there were still cases of discord between the communities: Hist. Patr. I8 (Evetts I9I0: I20-6).

7 See Papaconstantinou 2006, and the remarks in Décobert 2000: 24. 
being far from synonymous), and that there was more concord among Greek and Coptic speakers and less inter-confessional conflict than the anti-Chalcedonian Church cared to admit. ${ }^{8}$ Papyri do give a very different image of Christian society under the Umayyads and the first Abbasids than the one we can extract from other contemporary texts. One may object that papyri from that period are mainly fiscal or legal documents, a fact which could be enough to explain the absence of any sign of ethnic or religious conflict. However, those texts do have a strongly cultural content and, looked at closely, they give much information on the society that produced them and on its cultural choices, even though they never make direct comments about the 'Greeks' or the 'Romans'.

Among other things, papyri have helped establish the extent to which Byzantine documentary and administrative practice continued well after the conquest, as well as the fact that Greek remained a language largely used by the administration, not least because, initially, Christian officials kept their positions. ${ }^{9}$ This has been possible through the study of a series of archives, pertaining primarily to the taxation system. Of these, the Aphrodito papyri from the early eighth century are the most important, because they link up with other documents all related to the governor Qurra ibn Sharik (709-15), and allow some insights into the relation between local and central government. ${ }^{\mathrm{IO}}$ From roughly the same period is the significant group of papyri from Edfū (Apollōnos Anō), ${ }^{\mathrm{II}}$ while from the second half of the seventh century there are groups of documents from Isnā (Herakleopolis) and al-Ashmūneyn (Hermopolis). ${ }^{\mathrm{I2}}$

From the period immediately following Qurra's governorship, the most significant group of papyri are some 130 Coptic legal documents from the archives of a monastery in the Theban region. Stretching from 713 to the 780 s, they yield information on the legal and notarial practice, as well as on the social life of a small Christian community. ${ }^{13}$ Soon after their

${ }^{8}$ The strongest case has been made by Wipszycka 1992. See also Winkelmann 1979 and Winkelmann 1984. For the period before Chalcedon see Bagnall Egypt: 25I-60. The question of identity and allegiance in this period is complex, and involves much more than the usually cited religious and ethnic factors; an overview is given in Hoyland Islam: 17-26.

9 On administrative continuity, see Bell 1928 , and his introduction to P.Lond. IV xvii-xli; on the process of replacement of Greek by Arabic in the administration see $E I^{2}$, s.v. 'Dīwān, I'. See also Sijpesteijn 2004 and Sijpesteijn 2007.

Io A number of those texts are published in P.Qurra, P.Ross. Georg. IV and P.Lond. IV.

II See Gascou and Worp 1982.

${ }^{12}$ See for instance the documents published in CPR XXII, and the general presentation of early Islamic documentary sources therein, $\mathrm{I}-\mathrm{I} 6$.

${ }^{13}$ Initially published without a translation in Crum and Steindorff I9I2; German translations in Till 1954 and Till 1964. 
original publication in Coptic, the law historian Artur Steinwenter devoted several studies to those texts. To him, one of their greatest merits was that they served as proof of the persistence, over a century after the Arab conquest, of Byzantine notarial practice within Christian communities. ${ }^{14}$ Even though the original Greek formulae had often had to be translated into Coptic in order to be understood, he said, they remained so close to their model that it is possible to translate them back into Greek and obtain a legally acceptable text. ${ }^{I 5}$ The structure of the documents was also directly inherited from the east Roman tabelliones, and so were the 'norms and legal institutions they reveal to us'. ${ }^{16}$

To what extent is such structural continuity significant? All the above fields - taxation, administration, law - are notoriously conservative in their practice, and thus not the most telling when it comes to assessing the evolution of society. In the case of law, continuity of form is also quite natural given the legislative autonomy granted to Christian communities under Islam, although often the domain of civil law was at least partly incorporated in canon law collections. ${ }^{17}$ It is possible, however, to look at the same texts more closely from a different perspective, and to analyse them at a different level. They all contain a number of markers, independent of administrative or legal structures as such, that contrary to what the official discourse of rejection would have us believe, show a persistent cultural adherence to the model represented by the Byzantine Empire.

The continuing use of Greek in official documents is a case in point. To a certain extent it was rather natural, given the people with whom scribal, notarial and administrative activities rested. Greek scribal tradition was kept alive for some time by the Arabs themselves, not only in Egypt, but in all the ex-Roman provinces. ${ }^{{ }^{8}}$ It may however be seen as bearing greater significance as time went by, when it was no longer the language of bureaucracy and when traditional practice in Christian communities

\footnotetext{
${ }^{14}$ Steinwenter 1920. Is Steinwenter 1920: 2.

${ }^{16}$ Steinwenter I920: 2. Since Steinwenter's study, the relations of what has been called 'Coptic law' with its Roman and Egyptian (Demotic) predecessors have been at the centre of much debate, which need not concern us here; see the discussion in Richter Rechtssemantik: esp. 28-57. In fact, the very notion of Coptic law can be misleading, since it refers not to a distinct, unified body of legislation, but to the conclusions reached from the study of a series of independent archives from different places and times.

17 Edelby 2004.

${ }^{18}$ See the remarks in Sijpesteijn 2004 and Sijpesteijn 2005. According to the Chronicon ad a.C. I234, while Muhammad ibn Marwān was governor in Mesopotamia (685-710), 'the Christians were still the scribes, leaders and governors of the lands of the Arabs' (Chabot 1916: 294 [text] and Chabot I937: 229 [trans.]).
} 
was itself subject to change - or when it appeared in less predictable contexts. For instance, though it may still seem conceivable that the fiercely anti-Byzantine Monophysite patriarch Benjamin should have written his festal letters in Greek at the time of the Arab conquest, ${ }^{19}$ it is quite surprising to see Alexander II, also an anti-Chalcedonian patriarch, draw up his annual festal letter for 724 in Greek, at a time when Coptic had long become the official language of the patriarchate. ${ }^{20}$ Setting the annual date of Easter had for centuries been the exclusive prerogative of the Alexandrian patriarchate, and festal letters were meant to announce this date to the other churches, which could in itself explain their use of Greek even at a late date. In this way, post-conquest Monophysite patriarchs could symbolically lay claim to some sort of Christian universality and affirm institutional continuity with their pre-Chalcedonian predecessors.

The presence of Greek protocols and subscriptions in the Theban legal documents is perhaps more significant in this respect. These were private acts, not administrative documents. Many of them were written over a century after the conquest, in a non-urban context and in a region where Coptic had been the dominant language already in Byzantine times, even in official documents. For instance, although the will of bishop Abraham, the first abbot of St Phoibammon, drawn up around 6ro, was in Greek, ${ }^{21}$ that of his successor, dated 4 December 634, was bilingual. ${ }^{22}$ Bishop Abraham's own correspondence in the late sixth and early seventh century is entirely in Coptic. Of course, legal formulae tend to be repeated indefinitely even when, for their users, they have become empty, routine expressions. In general, however, most of the eighth-century Theban documents have the usual Greek formulae translated into Coptic, which may be the result of some form of anti-Hellenism, just as it may simply mean that the individuals involved in the transactions wished to understand them more thoroughly. Whatever the case (and the two are not mutually exclusive), this makes the ones that have kept the formulae in Greek stand out, and this deviation from the norm can arguably be interpreted as meaningful. It also means that these passages did not simply function as set phrases, but still carried some meaning.

Use of Greek often went hand in hand with the continuing use of late Roman honorifics and titles, and even with their transfer to Arab

\footnotetext{
19 P. Köln V 215 (CPG 7940, 3); extracts of two others (CPG 7940, I and 2) are quoted in a florilegium on Lent appended to one of John of Damascus's letters; see Müller 1968: 32 (extracts from letters 30 of 656 and 3I of 657).

${ }^{20}$ MacCoull 1990. $\quad{ }^{21}$ P.Lond. I.77 (p. 231); see Krause 1969: 58-60.

${ }^{22} P . K R U 77=S B$ I 4319; see Krause 1969: 60-2 and Bagnall and Worp 1979: 72-3.
} 
officials. ${ }^{23}$ Several documents from the decades following the Arab conquest show the practice was common throughout Egypt. In Hermopolis (al-Ashmūneyn), the pagarch Athanasios in the middle of the seventh

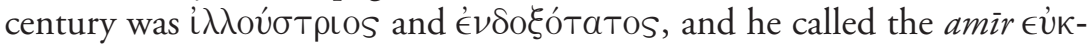
$\lambda \in \epsilon \in \sigma T a t o s .{ }^{24}$ In the first half of the eighth century, Rashìd ibn Khālid $(\mathrm{Pd} \boldsymbol{\omega} \mid \boldsymbol{\Delta} \Pi \boldsymbol{\Pi \omega} \boldsymbol{X} \boldsymbol{\lambda} \boldsymbol{\lambda} \in \boldsymbol{\Delta})$, amir of Herakleopolis and Hermopolis, was

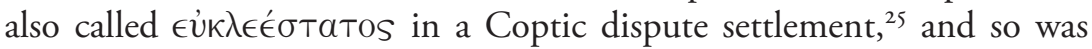
the amìr of Hermopolis Abū Sahl (двOY Cdd $\lambda$ ), also in the eighth century. ${ }^{26}$ Although to some extent this may be attributed to linguistic inertia, in fact things are probably not so simple. As these examples show, other terms such as amir were quite readily adopted, ${ }^{27}$ even in the case of officials who, though they bore Arab names, were perhaps neither Arabs nor Muslims, such as the aforementioned Abū Sahl, who was 'the son of

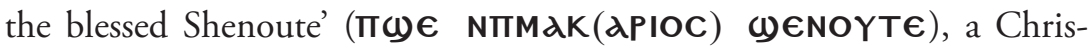
tian name, and thus at most a convert - or the father of a convert.

For the provincial governor, who was the highest official in the country, a new Greek term was coined, namely $\sigma u ́ \mu \beta o v \lambda o s$, which could stem from an attempt to Hellenise 'consul', ${ }^{28}$ since it went with the honorifics that had formerly qualified consuls, namely $\pi \alpha \nu \in \dot{u} \phi \eta \mu O S$ and $\dot{u} \pi \epsilon-$ фuéotatos (excellentissimus). Thus in the early eighth-century Coptic papyri from Aphrodito, the governor Qurra ibn Sharik is addressed as 'Our most praiseworthy lord Qurra, the most marvellous governor' (INXO€IC

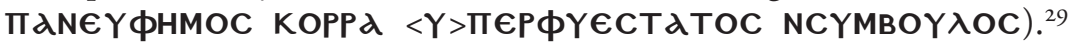

${ }^{23}$ On the use and evolution of honorifics Hornickel 1930 remains unreplaced.

${ }^{24}$ CPR XXII 2, 6 and CPR XXII I, I and I4; see also p. 2I, n. I on the use of honorifics in the early Arab period. The meaning of amir here is unclear, since it is commonly used to refer to the pagarch; see note 27 below.

${ }_{25}$ CPR IV 5I; on the archive of texts concerning Rashīd and on his actual position see Worp, I984: IOO-I.

${ }^{26}$ P.Ryl. Copt. 199, an acknowledgement of debt.

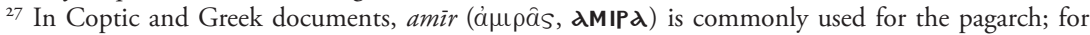
the same official, Arabic documents use șāhib, while amīr is there used for various higher officials: see Sijpesteijn 2004: 73-80; also Grohmann 1964.

28 This term was by no means confined to Egypt, and can even be found in Byzantine sources such as Theophanes, where it refers to the councillors surrounding the caliph Mu'awiya (Chron. AM 6I69,

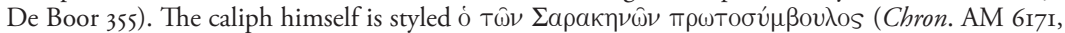
De Boor 356 and passim), a term also found in documents, for instance CPR VIII 82, 5: ov́oía tố

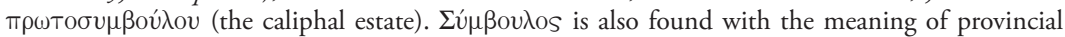
governor in an inscription from Gadara in Palestine; see Di Segni 1997: 237-40, no. 54 and fig. 50 ( 5 Dec. 662). In late seventh-century papyri from Nessana, however, the term is used to refer to the governor of the district (kura), who was equivalent to the pagarch: P. Nessana III 58, IO; 72, I;

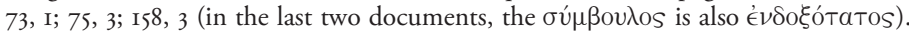

29 P.Lond. IV I494, II 6-7 (early eighth century). 
These honorifics, and even lesser ones, remained in use for quite a long time, and can still be found in the Theban legal documents in the second half of the eighth century, though often with devalued

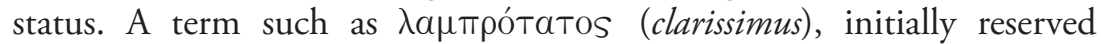

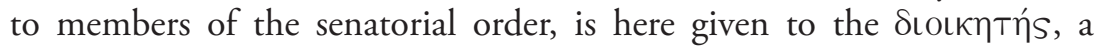
rather lowly official specifically attached to the town of Jème. ${ }^{30}$ As for

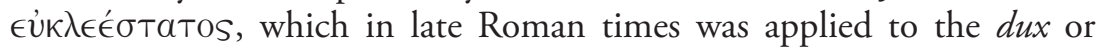
regional army commander, it is here used for the pagarch, who was the

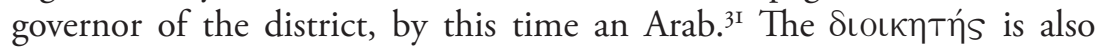

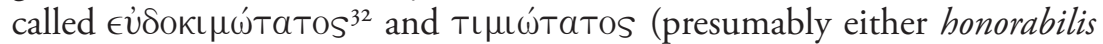

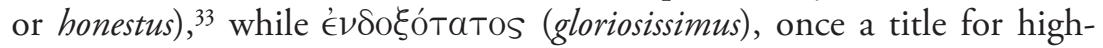
ranking officials, is also applied to him, ${ }^{34}$ as well as to the pagarch. ${ }^{35}$ Even important people without official positions are found to use honorifics,

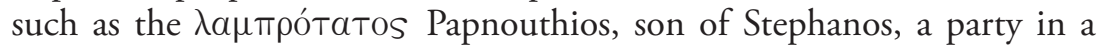
760 sale contract. ${ }^{36}$ The last term was evidently much appreciated, ${ }^{37}$ and it was even translated into Coptic, which implies it was still a meaningful term rather than an empty box. This is also indicated by the fact that, although they now embraced a much larger range of worthies, these honorifics seem on the whole to have retained their relative value, so that the highest were still given to the most important officials. ${ }^{38}$

What could bear even more weight in this respect is the totally gratuitous use in the Arab period of the classy Roman gentilicium 'Flavius' before the names of the same officials. As James Keenan has shown, as early as the fifth and sixth centuries, the names Flavius and Aurelius

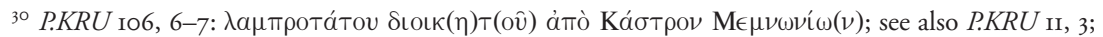

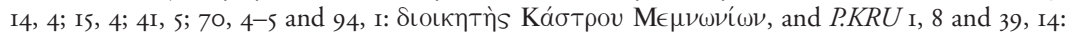

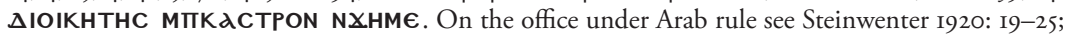

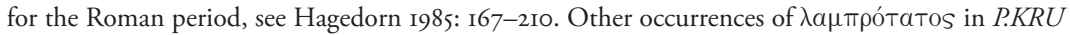
I, 6; 4, 3; IO, 3; 20, IO; 2I, 8; 22, 28; and 84, 2.

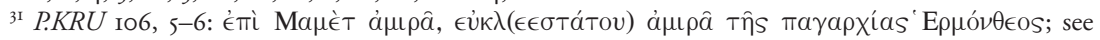
also P.KRU 8, 4; I0, 7-8; I2, 3; 13, 3; 25, I6; 30, 3; 47, 12; 50, 3; 52, 6 and 70, 3 .

${ }^{32}$ P.KRU 43, IO.

33 P.KRU 70, 4. The title was normally used for the two lashane (town magistrates, the rough equiv-

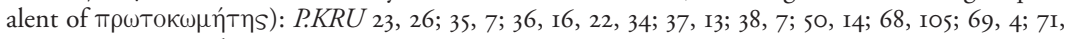
$3 ; 74,4 ; 105,25 ;$ and 122,3 .

34 P.KRU 39, I4; 4I, 21, 30; 43, I7 and 86, I0.

${ }^{35}$ P.KRU 25, I5; 42, 7-9 and 45, 3. The devaluation of honorifics is a long-term phenomenon, and had started well before the Arab conquest. In some rare cases, gloriosissimus can be found applied to the pagarch as early as the sixth century, e.g. CPR XIV II, 6; P.Lond. V I666, 4.

${ }^{36}$ CPR IV 26, 28.

${ }^{37}$ A 70 I mosaic inscription in a church at Aristobulias, today Khirbet Istabul, mentions Samuel $\lambda a \mu$ про́татоS as one of the authorities under whom the paving was done. Like Papnouthios, Samuel does not seem to have had an official position; see Di Segni 2003: 252-3.

${ }^{38}$ On similar phenomena in Italy, see Brown 1984: 138-42. 
had started losing their quality as gentilicia to become status designations, of which the former was clearly more elevated than the latter. ${ }^{39}$ This seems once again to have worked well into the early Islamic period. Towards the end of the seventh century, the pagarch of Herakleopolis

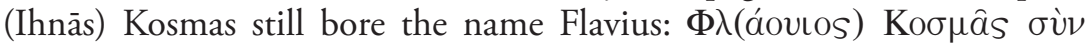

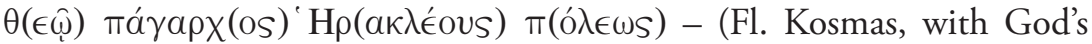
will pagarch of the city of Hercules) $4^{40}$ Around 730 , in a number of sale

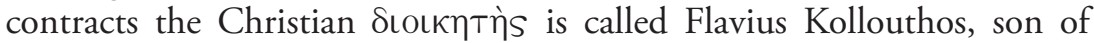
Arsenios, and the name of the person holding the same office in 756 is Flavius Komes, son of Chael. ${ }^{4 \mathrm{I}}$ Like the honorifics, this civility was extended to Arab officials. Two agreements on property dated 739 and 740 mention 'Flavius Sahl, son of 'Abd Allāh' ('́mì $\Phi \lambda(a$ ovíov) $\Sigma a \alpha \lambda$ viou $\mathrm{A} \beta \delta \in \lambda \lambda \alpha),{ }^{42}$ and ten years later, a will gives the name of the amir

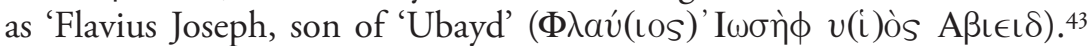
Needless to say, outside the late Roman system, the gentilicia could only have symbolic value, especially when bestowed upon Muslim officials. ${ }^{44}$

These observations can be combined with similar evidence from other fields, which tends to go the same way and thus to reinforce the impression that Greco-Roman values still enjoyed some prestige among Egyptian Christians. Dating formulae, for instance, generally gave the day of the month and the indiction year, followed by the name or names of the village or district officials. A number of documents, all in Greek, include the date by what is known as the Era of Diocletian. ${ }^{45}$ The most elaborate of the four, dated 3I May 735, runs as follows: ${ }^{46}$

39 Keenan 1973: 33-63; Keenan 1974: 283-304; Keenan 1983: 245-50.

${ }^{40} C P R$ XXII I4, I. See also the pagarch of Herakleopolis Flavius Menas mentioned in a document of 687/8 or 702/3: Gonis and Morelli 2000: 193-5.

${ }^{41}$ P.KRU 6, 3; II, 3; I4, 4; 15, 4; and 4I, 4 (Fl. Komes); P.KRU 27, 3 (Fl. Kollouthos), adding the

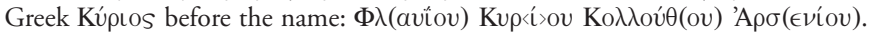

${ }_{42}$ P.KRU 45, 3 (24 April 740); see also P.KRU 50, 3 (22 August 739), without the name of the father.

${ }^{43}$ P.KRU 70, 3 (4 July 750 ).

${ }^{44}$ The suggestion has been made that its use could indicate converted aristocrats; see Gonis and Morelli 2000: 194. However, their Muslim patronyms mean they would be at least secondgeneration converts, in which case it is significant that they should retain the gentilicium.

45 These are P.KRU I4, 2-5 and I5, 2-5 (both dated 756), P.KRU 70, 2-5 (749/50), P.KRU I06, 4-9 (734/5), and perhaps P.KRU ioo (A. Diocl. $529=8 \mathrm{1} 2 / 1 \mathrm{1} 3$ ?)

${ }^{46}$ P.KRU 106, 4-9. The dating by the Era of Diocletian in this document does not correspond with AH II4, which should read II7. Till I962: 39 assumes that the former is right, and that II4 is a scribal mistake, presumably because the document is written by Christians and because that date also agrees with the indiction. This could however just as well have been misread by the editor, since $\boldsymbol{\Delta}$ and $\boldsymbol{Z}$ are quite easily confused, especially in the type of late majuscule used for numerals (I am grateful to Roger Bagnall for discussing this with me). In the absence of an accessible photograph of the papyrus I have refrained from correcting the date to $\rho \zeta^{\prime}$. 


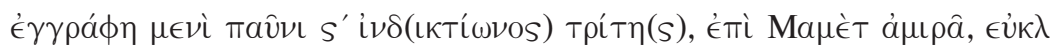

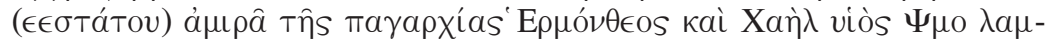

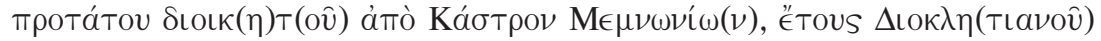

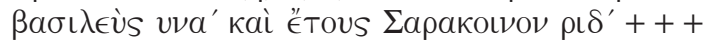

Written on 6 Pauni of the third indiction, under Muhammad the amir , the glorious amir of the district of Hermonthis and Chael, son of Psmo, the clarissimus dioiketes from the Kastron Memnonion, in the year 45I of Diocletian the emperor, and the year II4 of the Saracens.

This Era of Diocletian - starting at that emperor's accession in $284-$ first appeared in Egypt at the end of the fourth century, when it was limited to horoscopes and private inscriptions such as epitaphs and graffiti. It only started being used in documentary texts after the Arab conquest, first in the Fayyūm and, from the eighth century onwards, also in Upper Egypt. ${ }^{47}$ Roger Bagnall and Klaas Worp recently suggested that its slow generalisation 'may have arisen from the desire of Christian Egyptians for a means of reckoning more continuous than the indiction but other than the Saracene era', ${ }^{48}$ implying that the Christian communities may have wished to retain a link with the Christian empire through a form of post-regnal dating. As dating systems are naturally conservative, taking up an existing era - even that of the persecutor Diocletian - was the most expedient option.

Dates were probably the domain where Greco-Roman mannerism resisted best. The Era of Diocletian remained common until the eleventh century, and can even be found until the mid-fourteenth century, alongside the Era of the Martyrs, which was gradually to become the 'official' era of the medieval Coptic Church. Diocletian, however, was not the only possible link with the Roman past. Still in the early twelfth century, a scribe who copied the four Gospels for the White Monastery near Akhmim wrote the date on his manuscript's colophon in Greek, even mentioning the Roman month of April - an extremely rare occurrence and the Byzantine anno mundi next to the more predictable Egyptian month of Parmoute (March-April), the Era of the Martyrs and the Era of the Saracens. ${ }^{49}$

It is also noteworthy that in the text quoted above Diocletian is called basileus, a rather uncommon epithet in dating formulae. Evidently the office still retained a certain legitimacy for the person who drew up the

\footnotetext{
47 Bagnall and Worp 2003: 63-87, with a list of the sources bearing a date by that era, 68-82; MacCoull and Worp 1990.

${ }^{48}$ Bagnall and Worp 2003: 64 .

49 P.Lond.Copt. 489 = BM Or. 3581B(69); van Lantschoot 1929: 133-7, no. LXXX.
} 
document. This symbolic importance of the emperor can also be found elsewhere in Egypt after the Arab conquest. A late seventh- or early eighth-century epitaph from the monastic site at Kellia in Lower Egypt, for instance, mentions in its dating formula 'the reign of Justinian the emperor' - Justinian II (685-95 and 705-II) according to the archaeological context. ${ }^{50}$

A limited number of oaths by the 'salvation' or the 'victory' of the emperors also appear in documents from the years immediately after the Arab conquest. In 645, for instance, a document from Aphrodito contains the formula 'the almighty God and the victory of imperial salvation' (Tóv

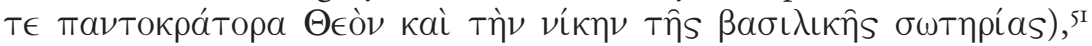
and in 647, the oath in a property settlement deed drawn up in Edfū (Apollōnos Anō) was taken 'by the Holy and Consubstantial Trinity

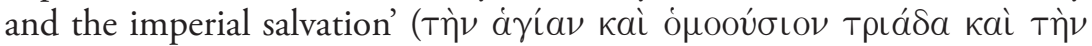
$\beta a \sigma \iota \lambda \iota \kappa \eta \nu \nu ~ \sigma \omega t \eta \rho i ́ \alpha) .52$ A more ambiguous oath formula, attested in Oxyrhynchos as early as $644 / 5$, referred in some way to any authority that has power over us', ${ }^{33}$ which paid allegiance to the Arab authorities without entirely excluding the idea that things could still change, contrary to another oath formula found in Hermopolite documents of the later seventh century, which plainly mentioned the salvation of our Lords

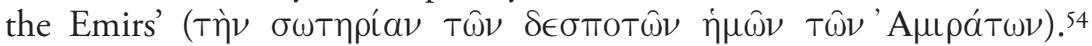
A century later, some Theban documents still mention 'the salvation of our Lords, that now govern us on God's orders', a phrase that may allude to the very common Christian interpretation of the Muslim conquest as a punishment from above, and thus still betray some attachment to the previous situation. 55

Some of the Jeme legal documents also refer in one way or another to 'the laws' they were supposed to be applying. In several donation deeds concerning children who were given as slaves to a monastery by their parents, the 'imperial laws' or the 'imperial order' (Tákıs) are invoked to justify the parents' right to act as they did; they are twice paired with the

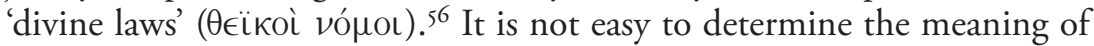

so Partyka and Kasser 1994: 448-9, no. 303.

51 P.Mich. XIII 662, I2; see Bagnall and Worp 2003: 106 for the date.

52 SB VI 8988, 79. 53 SB VI 8987, 39.

54 See Bagnall and Worp 2003: 289, and the remarks in Gascou 1999: 20. This 'acceptance' of Muslim rule naturally becomes more common in later documents: see for instance P.KRU 2I, 78-80 (I2 June 725); 35, 7I-4 (6 Oct. 7I9); 66, I7-I9 and 76, IO-I2 (first half of eighth century).

55 P.KRU I0, 28-9 (8 Dec. 722) and 74, 30-3 (28 Dec. 733 or 748). On the theme of God's wrath see Hoyland Islam: 524-6.

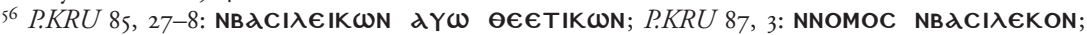

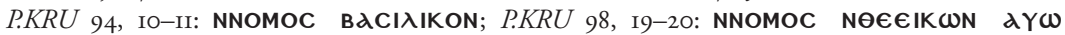


the term 'divine', since it could refer to the emperor as well as to a form of canon law. The latter hypothesis would, of course, correspond to the legislative reality of Christian communities in the Islamic world, and it is rather striking that the notaries did not leave it at that, but felt the need to add a reference to the 'imperial' laws - those of the neighbouring Christian empire. ${ }^{57}$ However one can not exclude the former possibility, namely that 'divine' also meant 'imperial', the two expressions being perhaps redundant, but clearly referring to Byzantine civil law. Of course, donating children as slaves to a monastery was in patent contradiction to Byzantine imperial legislation. This, however, does not diminish the symbolic value these laws retained in the eyes of those who invoked them: it indicates rather that the very mention of imperial law was enough to confer legitimacy on the practice, especially at a time when the possibility of checking Justinian's Code was quite remote. ${ }^{58}$

Greek forms also lingered in the case of city names, although an alternative toponymy in Coptic and Arabic was commonly used. Again, although this may have been natural at first, with time it became more conspicuous. In the Theban documents, the town most often mentioned is Jeme, which was built inside and around the ruins of the temple of Ramesses III at Medinet Habu. ${ }^{59}$ It is called the KdCTPON NXHM€ in Coptic, although it never had any military connection. The Greek pro-

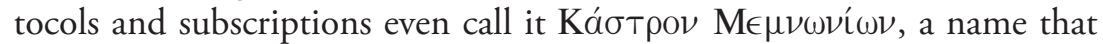
goes back to the early Roman period. Other Egyptian cities are also given their Greek names: Diospolis, Laton Polis, Kontra Laton, Tria Kastra, Antinoou. ${ }^{60}$ A witness signing in Greek around 700 went so far as to use not the usual Greek name of his city, but the honorific imperial name that had been given it by Justinian and was in official use only for a rather short time, namely 'the city of Justinian in Lower Egypt' ( $T \hat{\mathrm{T}} \mathrm{S}$

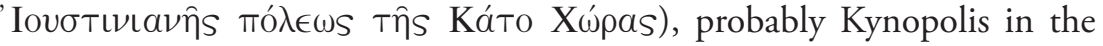

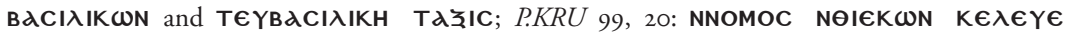

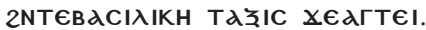

57 The expression $\theta \in i$ ios vónos was used before the conquest, probably referring to God's law: see Arangio-Ruiz 1920: 28-9.

${ }^{58}$ In fact, the justification sought in the laws is 'that it is possible for everyone to be master of that which belongs to him', which equates children with any other kind of property and does not refer to the specific laws concerning parents' rights and obligations; see for instance Cod. Just. 4.43, and more generally, Kaser 1975: 205-6.

59 For a general introduction to the western Theban region see Wilfong 1989 and, with more recent bibliography, Wilfong 2002: I-22.

${ }^{60}$ P.KRU 45, 3 (24 April 740); P.KRU 50, 3 (22 August 739); P.KRU 70, 3 (4 July 750); P.KRU Io, 7 (8 Dec. 722 ). 
nome of Busiris in the Delta ${ }^{6}{ }^{6}$ Greek names can be found until much later still: thus the aforementioned twelfth-century copyist who used Roman months for his dating also called Akhmim 'the Christ-loving city of Pan' (Пó $ı$ ıs Пavós). ${ }^{62}$

Perhaps the most interesting field for our purpose is that of onomastics. A close examination of the Jeme documents shows that the group of nomikoi favouring Greek protocols and subscriptions was relatively small. These were David son of Psate, Psate son of David, Senouthios son of Shemntsneu, Souhai son of Philotheos, Aristophanes son of John, Polykrates son of John, Job son of Alexandros, Psate son of Pisrael, the deacon Papas son of Kleonikos, the priest Elisaios and two monks, Zacharias and Apa Apater. One cannot but be struck by some of the names mentioned in this list. The relative density of 'high' Hellenic names within the scribes' families - Alexandros, Aristophanes, Polykrates, Kleonikos may of course partly be explained by the fact that nomikoi were part of the educated elite, and continued a tradition that was theirs before the conquest. In early seventh-century Hermopolis, for instance, the city's upper crust bore names such as Salloustios, Helladios, Polydeukes, Olympiodoros, Hermogenes or Aristophanes. ${ }^{63}$

The Theban west bank, however, was no Hermopolis. Before the conquest, what we know of Theban onomastics shows they were considerably less marked by such eccentricities. One may object that the bulk of Theban evidence for the first half of the seventh century comes from a very different type of archive, namely the 'professional' correspondence of the Monophysite bishop of Hermonthis, Abraham. ${ }^{64}$ Most of the individuals mentioned there are either members of the clergy or people seeking the bishop's help, while those in the eighth-century legal documents mostly belonged to the propertied strata of local society. It is not easy to know what naming patterns we might have found in a comparable group of private contracts and wills. It is noteworthy however that in the late seventh and

${ }^{61}$ P.CLT 5, I59; see Crum and Winlock 1926: 256, n. II and I04, n. I. Crum identifies the city as Koptos/Keft/Qifț, which had been Ioustinianoupolis for a short period, and expresses some surprise at the fact that the expression Kátw X $\omega ́ p a$ (Lower Egypt) had come to describe even a region so far south. It is perhaps more expedient to identify Ioustinianoupolis with a northern city, either Oxyrhynchos, which bore the name 'city of Justinian' with much pride in the sixth century, or, even more consistent with the location in Lower Egypt, Kynopolis of the Busirite nome: see Fournet 2002: 56 .

${ }^{62}$ P.Lond.Copt. 489 = Van Lantschoot, no. LXXX, lines 79-80: прмтாо $\boldsymbol{\lambda}$ (IC) ммג пє $\overline{\mathbf{X}} \overline{\mathrm{C}}$

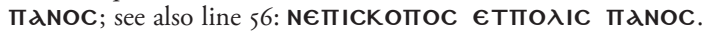

${ }^{63}$ P.Sorb. II 69, I05 Di; 69 B5; I27 Ci; I23 Bi; 42 B5; Iо $\mathrm{B}_{3}$ respectively; see also 53-4.

64 The texts are put together by Krause in his unpublished doctoral thesis (Krause 1956). The majority of the texts had been published in 1902 in $O$. Crum. 
especially in the eighth century, Greco-Roman names had become quite common, even in documents that were not legal, and were thus more representative of society as a whole. The majority were Greek names, such as Andronikos, Asklepios, Athenodoros, Herakleios, Ioannakios, Nikomachos, Olymbrios, Pelagios, Pergamios, Rhodakios, Stephanakios, Antheria, Archontia, Charisia, Martyria, Sophia, Thesauria. ${ }^{65}$ One also finds some Latin imperial names, such as Konstantinos or Pulkeria, ${ }^{66}$ as well as Roman institutions transformed into proper names, such as Illoustre, Tribounos, Hypatos, Romaios, Praipositos, Prinkipos or Komes. ${ }^{67}$

This, of course, was not a purely Theban phenomenon. Late seventhand early eighth-century documents from Aphrodito show that names with strong Greek or Roman flavour such as Euphemia, Archontia, Heraklios, Klaudios, Konstantinos, Oualentios or Philotim(i)os were also in use there. In the eighth century, one still finds Ptolemaios or Konstantinos, and even Aurelios Kyriakos in Bawit ${ }^{68}$ Anthimos or Staurakios in the Fayyūm, ${ }^{69}$ Aristoboulos, Aristophanes, Achileus, Helladios, Ioustinos or Philostorgios in Edfū, ${ }^{70}$ Achillites, Konstantinos, Diomedes or Magister in Bala'izah, ${ }^{71}$ as well as Euprepios and Eustochios in documents of uncertain provenance. ${ }^{72}$ To this one may add that the tendency to Hellenise Egyptian names, common in Greek-speaking Egypt from the very start, also continued well into the Arab period. In some Greek documents of the late seventh and the eighth centuries, one thus finds Пaxúpıos

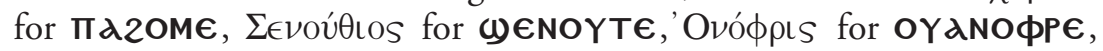

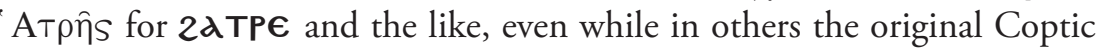
forms have prevailed.

Egyptian naming patterns had a strong local flavour, to the point that scholars today feel quite secure in assigning a provenance to a document on the basis of its onomastics alone. ${ }^{73}$ Names would have provided a

\footnotetext{
${ }_{65}$ Andronikos: O.CrumST 254; Asklepios, Sophia: O.Medin.HabuCopt. 40; Athenodoros: O.CrumST I43; Nikomachos: O.CrumST 50; Olymbrios: O.CrumST 260; Charisia: O.CrumST 191; Herakleios: O.Vind.Copt. 442; Ioannakios: P.KRU 67; 96; I07; Pelagios: OCrumST 91; Pergamios: P.Mon.Epiph. 269; Stephanakios: P.KRU I20; Rhodakios: P.Mon.Epiph. 435; Martyria: P.KRU 34, O.CrumST 424; Thesauria: P.KRU 28; Antheria: O.Brit.Mus.Copt. I 5I/3 (p. 68); Archontia: P.KRU 4.

${ }^{66}$ Konstantinos: O.Vind.Copt. 316, O.Brit.Mus. Copt. I 84/4 (p. I22); Pulkeria: O.CrumST I69.

${ }_{7}$ Illoustre: O.Vind.Copt. I65; Tribounos: BKU 73, O.Crum 373; Hypatos: O.Brit.Mus. Copt. I 84/4 (p. I22); Romaios: P.Mon.Epiph. I82; Praipositos: P.Mon.Epiph. 3II, O.Brit.Mus.Copt. I 85/2 (p. I23); Prinkipos: O.CrumST 9r. Komes is an extremely common name: see Till 1962: I2I-3.

${ }^{68}$ P.Mon.Apollo 48, 7; 43, 3; 48, 5. 69 CPR XXII I8, I6 (76I); I8, I7 (76I).

70 P.Apoll. 76B, 4; II, 6; 68, 13; 80, 6; 9, I6; II, 9; 5I, 5; 92B, 5 .

${ }^{71}$ P.Bal. 135; 290, 6; 292; 293, 5; 188, 19; 301, 9; 293, 5; 295, 4; 377.

${ }^{72}$ CPR XXII 38, 3 and 60, 30.

73 This was also true in other Near Eastern regions; see e.g. the tables showing the geographical distribution of Nabatean names in Negev I99I: 73-9, and the summary, 2.
} 
sense of local identity, and also set a norm from which one could not easily depart unnoticed, as in most traditional societies. The names singled out here marked a clear difference with mainstream onomastics in those areas. Next to the traditional local names, these were usually dominated throughout the seventh and eighth centuries by names from the Old Testament, which had the advantage of being totally neutral, even with respect to Islam. The New Testament was the next source, followed by the martyrs and a few monks. Thus in Theban district, the most common Old Testament names were Abraham, Isaac, Samuel, Moyses, Jacob, Aaron, Jeremias, David, Daniel and Solomon; from the New Testament came Petros, Markos, Matthaios, Maria and Stephanos, while popular martyrs' names were Phoibammon, Kyriakos, Victor, Georgios, Kollouthos and Menas, and monastic ones were limited to Pesynte and Onophrios. Names such as Kleonikos, Polykrates or Athenodoros clearly stood out, and it is difficult not to see them as the expression of some form of allegiance. Naming is always a potent statement of identity, especially in small communities or in the context of minority groups. ${ }^{74}$ Here, mainstream Christian names would have been the most obvious - and the most common - choice, and would also have been culturally neutral. On the other hand, ancient Greek or Latin names were rare, and they could only indicate a limited interest for the culture that went with them.

What can make such accumulation of scattered evidence compelling is the fact that the various elements often combine quite consistently. I will here take the example of one of the Theban nomikoi, Aristophanes, son of John. ${ }^{75} \mathrm{He}$ evidently came from a well-to-do family, and in the $740 \mathrm{O}$ and 750 s he owned both a house and land. He was active at least from 723 to 756 , and drew up a great number of documents that we still possess, among them several deeds on papyrus and shorter texts on ostraka, and he sometimes also signed as a witness. Aristophanes invariably signed his documents in Greek, and in the legal documents he also wrote the protocols and introductions in Greek. Several tax receipts written entirely in Greek are also in his hand. ${ }^{76} \mathrm{He}$ always used 'Flavius' and never forgot the honorifics, as if he were still in the Roman Empire. However, he was

${ }^{74}$ On the significance of 'deviant' naming practices see Herzfeld 1982. More generally on the social relevance of personal names see Alford 1988 and Lieberson 1984 .

75 On Aristophanes, see Till 1962: 6I-2.

${ }^{76}$ Crum and Winlock 1926: 256, n. I4 = Louvre, ostr. E 6262; O.Petr. 468; Worp 1986: I44-6, no. I7 (= SB XIX I4037); and Chrysi Kotsifou informs me that she is in the process of publishing one such receipt from the ostraka collections of the Catholic University of America, and that photographs of three more are among the papers of Nathaniel Reich at the Center for Advanced Jewish Studies in Philadelphia, but their current location is unknown. 
almost certainly born after 700, of parents who were themselves born after the conquest. He may have had a younger brother in the same business, since we know of a certain Polykrates, also son of John, who drew up a document around 770, fourteen years after the last dated text by Aristophanes. Even if the two were not brothers, that second-generation dhimmi families should choose such names for their children in the first half of the eighth century was unusual enough for it not to be thought the repetition of a meaningless tradition, but rather the result of some form of choice. It is certainly not without significance that it was precisely Aristophanes who wrote the most sophisticated 'Greek' documents, thus taking up for himself his parents' statement of identity and even transforming it, if one may so put it, into an act of allegiance to the Roman - or Christian - Empire.

Some of the documents quoted above were drawn up by people who were born before or just after the Arab conquest, and it is not surprising that they did not immediately change their attitudes. Most of them also came from cities, where both the Greek language and late Roman institutions had been quite deeply entrenched. For our purpose, the interest of the Jème documents lies above all in their date and origin, and the coherence with which they combine all the above elements. Living far from Alexandria in a region that had known several uprisings against Roman rule, this Coptic-speaking, anti-Chalcedonian community whose life was intimately linked with that of the (locally at least) powerful monastery of St Phoibammon could hardly be more typical of what the learned tradition depicts as the 'indigenous', Rome-hating Copts. Still in the second half of the eighth century, however, the documents they produced point to the persistence among them of the east Roman - or Byzantine - model. Even though this may not exactly be, to paraphrase Peter Brown, 'a statement of classical values which we do not expect to hear from inhabitants of Upper Egypt in the age just before Charlemagne', 77 Walter Crum's dismissal of the practice of the nomikoi who wrote in Greek as 'affectation' is perhaps a little too hasty. ${ }^{78}$

Of course, these practices mainly took place among a non-representative elite group. One may ask, therefore, what is the relevance of the cultural choices of such a group for the community as a whole? Can we infer that adherence to the Greco-Roman model was prevalent among ordinary

\footnotetext{
77 Brown 2003: 312, concerning a statement by Anthony of Tagrit on the quality of Greek learning. The original text has, 'It is a statement of classical values which we do not expect to hear from an inhabitant of Mesopotamia in the age of Charlemagne.'

${ }^{78}$ Crum and Winlock 1926: 256.
} 
Thebans? Or was it just an internal game among the cultivated elites? As always, the common man's attitude and feelings will remain out of our reach. One can hardly imagine, however, that the fancies of the town elite worked within a totally closed circuit. The very possibility of such a pose does imply that Greco-Roman culture and the Byzantine Empire that now carried it still enjoyed a certain level of prestige, sufficiently recognised by those who were excluded for it to function as a status symbol. Certainly the dynamics of social domination also played a role in the adoption of such attitudes, as they had in late Roman times. ${ }^{79}$ What the documentary evidence tells us is also certainly more representative, even if it only concerned the elites, than what we can make out from other sources, which are mainly the vehicles of ecclesiastical discourse. It is also quite clear that this attraction for Byzantine forms did not stem from institutional links with the Empire, such as a Chalcedonian community might have had. Among the notaries writing in Greek were some members of the clergy and some monks, all from non-Chalcedonian institutions, showing that even in those circles, the radical anti-Greek discourse of what was becoming the Coptic church did not have the totalising effect it sought. The isolation of the Jême community may of course in part explain its lingering Roman taste, and the fact that it probably took more time than urban societies to tune into the new system of values that gradually became prevalent in important cities - a system structured around the Coptic church elites and their 'nativist' discourse. Lingering Romanitas, however, was also to be found in cities and, as we have seen with the 724 festal letter, even at the heart of the Coptic patriarchate.

In the I960s, John Meyendorff wrote that his impression from reading John of Damascus was 'that of John living in a Christian ghetto which preserves intact the Byzantine political and historical outlook', praying for 'the victory of the emperor over his enemies', and being more interested in the 'iconoclastic heresy' than in the 'beliefs of the Arab conquerors'. Meyendorff concluded, 'In mind and heart John still lives in Byzantium. ${ }^{80}$ This view of John of Damascus living 'in a Christian ghetto' is of course misleading, considering that at the time, Christians were still the majority of the population and, as mentioned above, still held important positions within the Muslim administration - which, by the

\footnotetext{
79 See Herzfeld 1982: 290, who argues that exceptional naming practices will only function within a given system, and that rules are 'something that people actively manipulate to express their own position in the social world'. On the symbolic significance of the use of Greek in the west, see Berschin 1988: 18-32 and more generally, Goldhill 2002.

${ }^{80}$ Meyendorff I964: II7-18.
} 
way, was the case of John himself, as well as his father and grandfather before him. ${ }^{8 \mathrm{r}}$ But there is much truth in the description of his relationship to Byzantium. John was a Chalcedonian who was quite naturally concerned about the fate of the Chalcedonian Church, which was the imperial Church and whose centre was Constantinople. This was not the case of contemporary Thebans, at least not those who were in the nonChalcedonian network of St Phoibammon. Neither Aristophanes nor any of the others seemed at all interested in the iconoclastic 'heresy', which as far as they were concerned was nothing but a 'sub-heresy' anyway. Yet in some ways their situation resembled John's, in that they lived in a cut-off Christian world where the lost Christian empire seems to have retained its allure. They still inhabited its cities, referred to its laws, bore the names of its emperors, used its language as a sign of distinction and bestowed upon their new lords the honorific titles of their predecessors. Without overstating things, one might say that in mind and heart, Aristophanes and his friends still lived in Byzantium - in the Byzantium their great-grandfathers had known.

\section{BIBLIOGRAPHY}

Alford, R.D. (1988) Naming and Identity: A Cross-cultural Study of Personal Naming Practices. New Haven, Conn.

Arangio-Ruiz, V. (1920) 'Applicazione del diritto giustinianeo in Egitto', Aegyptus I: $2 \mathrm{I}-36$.

Bagnall, R. S. and Worp, K.A. (1979) Regnal Formulas in Byzantine Egypt, BASP Suppl. 2. Missoula, Mont.

Bagnall, R.S. and Worp, K.A. (2003) 'The Era of Diocletian and of the Martyrs', in The Chronological Systems of Byzantine Egypt, 2nd edn. Leiden: 63-87.

Bell, H. I. (1928) 'The Administration of Egypt under the 'Umayyad khalifs', $B Z$ 28: $278-86$.

Berschin, W. (1988) Greek Letters and the Latin Middle Ages: From Jerome to Nicholas of Cusa, trans. J. C. Frakes. Washington, DC.

Brown, P. (2003) The Rise of Western Christendom, 2nd edn. Oxford.

Brown, T.S. (1984) Gentlemen and Officers: Imperial Administration and Aristocratic Power in Byzantine Italy, 554-800. Rome.

Chabot, J.B. (ed.) (r916) Chronicon ad annum Christi I234 pertinens vol. I. CSCO 81, Scr. Syr. 36. Paris.

(trans.) (1937) Chronicon ad annum Christi I234 pertinens vol. III, CSCO Io9, Scr. Syr. 56. Paris.

${ }^{81}$ The most critical and up-to-date presentation of John's biography is Conticello 2000. 
Conticello, V. (2000) 'Jean Damascène', in Dictionnaire des philosophes antiques vol. III, ed. R. Goulet. Paris: 989-I003.

Crum, W.E. and Steindorff, G. (I9I2) Koptische Rechtsurkunden aus Djême (Theben): Texte und Indices vol. I. Leipzig.

Crum, W.E. and Winlock, H.E. (1926) The Monastery of Epiphanius at Thebes vol. I: The Archaeological and Literary Material. New York.

Debié, M. (2004) 'Place et image d'Antioche chez les historiens syro-occidentaux', Topoi suppl. 5: 169-70.

Décobert, C. (2000) 'Introduction: Formes et substances des construits identitaires', in Valeur et distance: Identités et sociétés en Égypte, ed. C. Décobert. Paris: 9-34.

Di Segni, L. (I997) 'The Greek Inscriptions of Hammat Gader', in The Roman Baths of Hammat Gader: Final Report, ed. Y. Hirschfeld. Jerusalem: 237-40. (2003) 'Christian Epigraphy in the Holy Land: New Discoveries', Aram 15: 247-67.

Edelby, N. (2004) 'The Legislative Autonomy of Christians in the Islamic World' (translation of an article first published in 1951), in Muslims and Others in Early Islamic Society, ed. R. Hoyland. Aldershot: 37-82.

Evetts, B. (ed. and transl.) (I9Io) 'History of the Patriarchs of the Coptic Church of Alexandria, III, Agathon to Michael I (766)', in Patrologia Orientalis vol. V. Paris: $3-215$.

Flusin, B. (1998) 'Évêques et patriarches: les structures de l'Église impériale', in Histoire du christianisme: Les églises d'Orient et d'Occident (432-6Io) vol. III, ed. L. Pietri. Paris: 507-43.

Fournet, J.-L. (2002) 'Coptos gréco-romaine à travers ses noms', Topoi suppl. 3: 47-6o.

Frend, W.H.C. (1972) The Rise of the Monophysite Movement. Cambridge.

Gascou, J. (I999) 'Edfou au Bas-Empire d'après les trouvailles de l'IFAO', in Tell-Edfou soixante ans après: Actes du colloque franco-polonais, Le Caire Is octobre I996. Fouilles franco-polonaises 4. Cairo: 13-20.

Gascou, J. and Worp, K.A. (1982) 'Problèmes de documentation apollinopolite', ZPE 49: 83-95.

Goldhill, S. (2002) Who needs Greek? Contests in the Cultural History of Hellenism. Cambridge.

Gonis, N. and Morelli, F. (2000) 'A Requisition for the "Commander of the Faithful": SPP VIII I082 Revised', $Z P E$ 132: 193-5.

Gray, P.T.R. (2005) 'The Legacy of Chalcedon: Christological Problems and their Significance', in The Cambridge Companion to the Age of Justinian, ed. M. Maas. Cambridge: 215-38.

Grohmann, A. (1964) 'Der Beamtenstab der arabischen Finanzverwaltung in Ägypten in früharabischer Zeit', in Studien zur Papyrologie und antiken Wirtschaftsgeschichte Friedrich Oertel zum achtzigsten Geburtstag gewidmet, ed. H. Braunert. Bonn: I2O-34.

Hagedorn, D. (1985) 'Zum Amt des Dioiketes im römischen Ägypten', YClS 28: I67-2IO. 
Herzfeld, M. (1982) 'When Exceptions Define the Rules: Greek Baptismal Names and the Negotiation of Identity', Journal of Anthropological Research 38: 288-302.

Hornickel, O. (1930) Ehren- und Rangprädikate in den Papyrusurkunden: Ein Beitrag zum römischen und byzantinischen Titelwesen. $\mathrm{PhD}$ diss. Giessen.

Kaser, M. (1975) Das römische Privatrecht vol. II: Die nachklassischen Entwicklungen, Handbuch der Altertumswissenschaft IO.3.3.2. Munich.

Keenan, J. G. (1973) 'The Names Flavius and Aurelius as Status Designations in Later Roman Egypt', $Z P E$ II: 33-63.

(1974) 'The Names Flavius and Aurelius as Status Designations in Later Roman Egypt' (part 2), ZPE ı3: 283-304.

(1983) 'An Afterthought on the Names Flavius and Aurelius', ZPE 53: 245-50.

Krause, M. (1956) 'Apa Abraham von Hermonthis: Ein oberägyptischer Bischof um 6oo.' Unpublished $\mathrm{PhD}$ diss. Berlin.

(1969) 'Die Testamente der Äbte des Phoibammon-Klosters in Theben', MDAI (Kairo) 25: 57-67.

Lieberson, S. (1984) 'What's In a Name? Some Sociolinguistic Possibilities', International Journal for the Sociology of Language 45: 77-87.

MacCoull, L.S.B. (1990) 'The Paschal Letter of Alexander II, Patriarch of Alexandria: A Greek Defense of Coptic Theology under Arab Rule', DOP 44: 27-4O, reprinted in MacCoull (1993) as no. XIX.

(1993) Coptic Perspectives on Late Antiquity. Aldershot.

MacCoull, L. S. B. and Worp, K. A. (1990) 'The Era of the Martyrs', in Miscellanea papyrologica in occasione del bicentenario dell'edizione della Charta Borgiana vol. II, eds. M. Capasso, G. M. Savorelli and R. Pintaudi. Florence: $375-408$.

Meyendorff, J. (1964) 'Byzantine Views of Islam', DOP I8: II3-32.

Müller, C. D. G. (1968) Die Homilie über die Hochzeit zu Kana und weitere Schriften des Patriarchen Benjamin I. von Alexandrien. Abhandlungen der Heidelberger Akademie der Wissenschaften, philos.-hist. Klasse I. Heidelberg.

Negev, A. (1991) Personal Names in the Nabatean Realm. Qedem 32. Jerusalem.

Papaconstantinou, A. (2006) 'Historiography, Hagiography, and the Making of the Coptic "Church of the Martyrs" in Early Islamic Egypt', DOP 60: $65-86$.

Partyka, J. and Kasser, R. (1994) 'Choix d'inscriptions provenant d'autres ermitages des Qouçoûr er-Roubầîyât', in Explorations aux Qouçoûr er-Roubâầyât: Rapport des campagnes I982 et 1983. EK 8184 2, ed. P. Bridel and N. Bosson. Louvain: 443-9.

Sijpesteijn, P.M. (2004) 'Shaping a Muslim State: Papyri Related to a Mideighth-century Egyptian Official'. Unpublished PhD diss. Princeton University.

(2005) 'Multilingualism in Late Antique Egypt', paper given at the Translated Texts for Historians 2oth year conference, University of Liverpool, June 2005 . 
(2007) 'The Arab Conquest of Egypt and the Beginning of Muslim Rule', in Egypt in the Byzantine World, 450-700, ed. R.S. Bagnall. Cambridge: 437-59.

Steinwenter, A. (1920) Studien zu den koptischen Rechtsurkunden aus Oberägypten. SPP 19. Leipzig.

Till, W.C. (1954) Erbrechtliche Untersuchungen auf Grund der koptischen Urkunden. Vienna.

(1962) Datierung und Prosopographie der koptischen Urkunden aus Theben. Vienna.

(1964) Koptische Rechtsurkunden aus Theben. Vienna.

Van Lantschoot, A. (1929) Recueil des colophons des manuscrits chrétiens d'Égypte. Louvain.

Wilfong, T. (1989) 'Western Thebes in the Seventh and Eighth Centuries: A Bibliographic Survey of Jême and its Surroundings', BASP 26: 89-I45.

(2002) Women of Jeme: Lives in a Coptic Town in Late Antique Egypt. Ann Arbor, Mich.

Winkelmann, F. (1979) đ̈gypten und Byzanz vor der arabischen Eroberung', ByzSlav 40: I6I-82.

(1984) 'Die Stellung Ägyptens im oströmisch-byzantinischen Reich', in GraecoCoptica: Griechen und Kopten im byzantinischen Ägypten, ed. P. Nagel. Halle: II-35.

Wipszycka E. (1992) 'Le nationalisme a-t-il existé dans l'Égypte byzantine?' JJP 22: 83-I28, reprinted in Wipszycka (1996), 9-6I.

(1996) Études sur le christianisme dans l'Égypte de l'antiquité tardive. Rome.

(2007) 'The Institutional Church', in Egypt in the Byzantine World, 450-700, ed. R. S. Bagnall. Cambridge: 33I-49.

Worp, K.A. (1984) 'Studien zu spätgriechischen, koptischen und arabischen Papyri', BSAC 26: 99-107.

(1986) 'More Ostraka from the Heerlen Collection', ZPE 66: I3I-47. 